J. Dairy Sci. 95:2299-2306

http://dx.doi.org/10.3168/jds.2011-4785

(C) American Dairy Science Association ${ }^{\circledR}, 2012$.

\title{
No seasonal effect on culturable pseudomonads in fresh milks from cattle herds
}

\author{
F. Leriche ${ }^{1}$ and K. Fayolle \\ Clermont Université, VetAgro Sup, UR CALITYSS, BP 10448, F-63000, Clermont-Ferrand, France
}

\begin{abstract}
Freshly drawn raw milk from 37 single herds on farms manufacturing raw cow cheese under the Protected Designation of Origin (PDO) label were sampled over 13 mo for pseudomonad counts. Coliforms, somatic cells, and coagulase-positive staphylococci were counted and total fat and protein contents measured. For pseudomonad counts, the overall mean value was $3.60 \times 10^{3}$ $\mathrm{cfu} / \mathrm{mL}$. We observed very high variation between different producers and within the same producers (average standard deviation $1.30 \times 10^{4} \mathrm{cfu} / \mathrm{mL}$ ), but we did not detect a seasonal effect. The only statistical correlation with other milk quality parameters was with coliforms. A survey of milking practices and milking machine sanitation together with environmental and milk sampling for pseudomonad counts in 7 cheese workshops showed that no real negligence or error could be imputed to producers. The main problems were the presence of non-aeruginosa pseudomonads in potable water and a few isolated failures during the cleaning and rinsing phases of sanitation.
\end{abstract}

Key words: raw milk, cheese, Pseudomonas

\section{INTRODUCTION}

For several decades, dairy farming and cheesemaking professionals have been making considerable efforts to improve the sanitary quality of their finished products. These efforts include all stages of production, manufacturing, and marketing with, in particular, better control of the sanitary state of the herds and the sanitary conditions of milking and processing. Refrigeration and maintenance of milk at low temperature $\left(1^{\circ} \mathrm{C}\right.$ to $\left.6^{\circ} \mathrm{C}\right)$ between milking and processing were introduced to slow down the growth of most pathogenic microorganisms, while also offering more flexibility in the organization of milk collection and processing. These practices led not only to a general decrease in milk total bacterial

Received July 29, 2011.

Accepted December 29, 2011.

${ }^{1}$ Corresponding author: f.leriche@vetagro-sup.fr counts, but also to equilibrium changes among different groups in the milk bacterial community (Jaspe et al., 1995; Leitner et al., 2008; Verdier-Metz et al., 2009; De Jonghe et al., 2011). Refrigerated storage has created selective conditions for the growth of psychrotrophic bacteria, which have optimal and maximal growth temperatures above $20^{\circ} \mathrm{C}$ but are still able to grow at low temperatures (Morita, 1975). In milk and dairy products, psychrotrophic bacteria are very diverse, including both gram-positive species (Bacillus, Clostridium, Corynebacterium, Microbacterium, Micrococcus, Streptococcus, Staphylococcus, and Lactobacillus) and gramnegative species (Pseudomonas, Aeromonas, Serratia, Acinetobacter, Alcaligenes, Achromobacter, Enterobacter, Flavobacterium, Burkholderia, Sphingomonas, Stenotrophomonas; Cousin and Marth, 1977; Sørhaug and Stepaniak, 1997; Munsch-Alatossava and Alatossava, 2006; Hantsis-Zacharov and Halpern, 2007). Of these, Pseudomonas spp. are considered predominant, with counts ranging from $<10 \%$ to $>75 \%$ of the total bacterial count of milk (Richard and Houssu, 1983; Ternström et al., 1993; Jaspe et al., 1995; Wiedmann et al., 2000; Dogan and Boor, 2003; Gunasekera et al., 2003). As contaminants of cheeses, Pseudomonas spp. can induce serious defects such as yellowish, green-tobrownish, or blue coloration of cheese surfaces (Martin et al., 2011a); poor development of ripening flora; and undesirable flavor and melting texture (Champagne et al., 1994; Ledenbach and Marshall, 2009), all of which are responsible for product depreciation and thus economic losses. Such deterioration is mainly attributed to the enzymatic activities of Pseudomonas and their metabolic by-products (for reviews, see Fairbairn and Law, 1986; Champagne et al., 1994). In the last decade, most relevant reports have concerned the identification or characterization of Pseudomonas species or, more largely, of psychrotrophic bacteria isolated from milks after storage at low temperature, but surprisingly, very few studies have been conducted on the quantification of Pseudomonas and related species in milk just after milking. We chose Saint-Nectaire farmhouse raw milk cheese as a model to study the presence of pseudomonads at the earliest stage of processing, from herd to milk tank. Indeed, for Saint-Nectaire cheeses, milk qual- 
ity comes close to the national standard, but spoilage attributed to Pseudomonas is one of the problems most often mentioned by ripeners: $95 \%$ state that they are or have been confronted with it and report a marked seasonal effect, with autumn and spring being critical periods. The purpose of the present work was to quantify the culturable Pseudomonas and related species (i.e., pseudomonads) in nonrefrigerated raw cow milk, assess seasonal variation, and seek correlations with other descriptors of milk quality and hygiene practices at the milking level.

\section{MATERIALS AND METHODS}

\section{Raw Milk Samples}

Milks sampled for this study were used for the manufacture of the traditional semihard raw-milk SaintNectaire cheeses under the Protected Denomination of Origin (PDO) label. This label means that producers have complied with strict production guidelines and charters that, among other things, specify and regulate the management of animals concerning genetics, physiology, and feeding. For example, permanent grasslands represent $90 \%$ of the farm's useful agricultural area and cattle graze a minimum of $140 \mathrm{~d} / \mathrm{yr}$, although no particular breed is specified. Concerning the process, in each farmhouse, cheeses are handmade after each milking session from the farmer's own herd twice a day all year long with no cold temperature storage or milk heating. After processing, the cheeses can be either matured on the farm or sold to cottage-scale or industrial ripeners; in both cases, during the 4 wk of ripening, cheeses are hand-washed every week with salted water or are dry salted. Thirty-six farmhouse workshops producing the PDO cheese were chosen among 250 spread over 1,900 $\mathrm{km}^{2}$ of uplands, on the following criteria: geographical distribution in the PDO zone, quality of milks (all met European Union standards), and willingness of farmers to participate. The mean number of cows milked in farms during the study was 54 (range 32 to 88). Milk samples were collected monthly for 13 mo in each farm. They were taken from the tank milk just after milking and before addition of rennet and starters at $32^{\circ} \mathrm{C}$. All raw milk samples were collected under sterile conditions, chilled to $4^{\circ} \mathrm{C}$, and taken for laboratory analysis within the next $6 \mathrm{~h}$.

\section{Microbial and Chemical Analysis}

Pseudomonads were enumerated on cetrimide-fucidine-cephalosporin (CFC) agar supplemented with 10 $\mathrm{mg} / \mathrm{L}$ cetrimide, $10 \mathrm{mg} / \mathrm{L}$ fucidine, and $50 \mathrm{mg} / \mathrm{L}$ cepha- losporin as selective agents (Oxoid Ltd., Basingstoke, UK) after incubation at $25^{\circ} \mathrm{C}$ for $48 \mathrm{~h}$. Coagulase-positive staphylococci were counted on Baird Parker agar (Oxoid Ltd.) with rabbit plasma after incubation at $37^{\circ} \mathrm{C}$ for $48 \mathrm{~h}$ by the ISO $6888-2$ standard method (ISO, 1999). Total coliforms were counted on violet red bile lactose agar (Oxoid Ltd.) after incubation for $48 \mathrm{~h}$ at $30^{\circ} \mathrm{C}$ by the NF V08-050 standard method (ISO, 2009). Somatic cell counts were determined with the NF EN ISO 13366-1 standard method (ISO, 2008). Milk fat and protein contents were determined by mid-infrared assay using the NF ISO 9622 standard method (ISO, 2000).

\section{Milking Practices and Pseudomonad Counts in Milk and Water}

Seven dairy workshops were selected based on their previous history of pseudomonad contamination of cheese, the quality of their milk, and the willingness of the farmers to participate. Their milking practices were described by survey during the morning milking period. The survey concerned the hygiene practices applied to udders, the air quality in the animal housing, the cleanliness of the milking parlor environment, and the parameters of milking machine sanitizing. Evaluation was performed according to a simplified method adapted from the charts described by Ferré (2003) and Sauvée (2007). Each criterion was scored on a 3-level scale: poor, moderate, or satisfactory.

These observations were accompanied by microbial evaluation of milk and water at different points of the milking process. Milk samples were collected at the very beginning of milking (first throw of the milking machine; $\mathrm{n}=7$ ), in the tank before starter addition $(\mathrm{n}=7)$, and at the draining point of the machine ( $\mathrm{n}$ $=5)$. Swabs were taken on teats $(\mathrm{n}=38 ; 10 \%$ dairy cow $)$, on the filters $(n=6)$ of the milking machine, and on its rubber cups $(\mathrm{n}=56)$. After estimation of the surface areas of swabbed parts, the swabs were taken using flexible sterile sticks with Letheen broth to transport the samples and to neutralize the action of cleaning residues before analysis. The samples underwent enumeration of pseudomonads as described previously. The results for the samples obtained by swabs were expressed in colony-forming units per centimeter squared. Water samples were collected aseptically and filtered using $0.45-\mu \mathrm{m}$ cellulose nitrate filters (Sartorius AG, Göttingen, Germany). The filters were then placed on CFC agar plates and incubated as described previously. Water containing residual chlorine disinfectant was sampled in bottles containing sodium thiosulfate as a dechlorinating agent. 


\section{Statistical Analysis}

In total, 1,955 data points from milk analysis were collected using Excel software and processed using Excel (Microsoft Corp., Redmond, WA), Statgraphics 5.0 (Manugistics Group Inc., Rockville, MD), Uniwin Plus (Sigma Plus, Paris, France), or XL Stats (Addinsoft, New York, NY) software; several data points were excluded when 1 or 2 parameters were not available. The effect of period of sampling (month or season) on pseudomonad counts and other milk quality parameters was tested by ANOVA. Differences were considered significant at $P<0.05$. The Pearson correlation test was used to assess correlations between the pseudomonad concentrations and the other parameters, while concentrations of pseudomonads, coagulase-positive staphylococci, total coliforms, and total fats and total proteins were normalized for principal component analysis (PCA). Hierarchical clustering, calculated on a "medium link" basis, was performed on the arithmetic means of pseudomonad concentrations and likewise for other microbial data.

\section{RESULTS AND DISCUSSION}

\section{Seasonal Variations of Pseudomonad Counts and Correlations with Other Milk Quality Parameters}

Our data from the monthly sampling of fresh milks in 37 farmhouses during a 13-mo period indicated an average value of $3.60 \times 10^{3} \mathrm{cfu} / \mathrm{mL}$ (arithmetic mean) and a standard deviation of $1.30 \times 10^{4}$ for the aggregated data for pseudomonads as counted on CFC agar plates. These results were similar to those of Gennari and Dragotto (1992), who found counts of Pseudomonas in 20 bulk raw milks between $1.00 \times 10^{3}$ and $1.00 \times 10^{5}$ $\mathrm{cfu} / \mathrm{mL}$ using a similar protocol. They were also consistent with the data of De Jonghe et al. (2011), who recently recorded an average value of $3.16 \times 10^{2} \mathrm{cfu} /$ mL of pseudomonads in milk samples collected just after milking $(\mathrm{n}=8)$. In 1997, Desmasures and Gueguen (1997) showed that geometric means of pseudomonads in refrigerated milks from 4 farms collected monthly for 6 mo ranged from $5.20 \times 10^{2}$ to $2.60 \times 10^{3} \mathrm{cfu} / \mathrm{mL}$, the authors noted that the proportion of Pseudomonas in the total bacterial count ranged from 0 to $100 \%$. We also observed this effect: the differences between milks from 2 successive months from the same producer and herd ranged from negligible to more than $7.50 \times 10^{4}$ $\mathrm{cfu} / \mathrm{mL}$, whereas no major change in herd management practices could be observed.

Because ripeners also noted seasonal variations in cheese spoilage by pseudomonads (peaks in spring and autumn), we evaluated monthly or seasonal variations

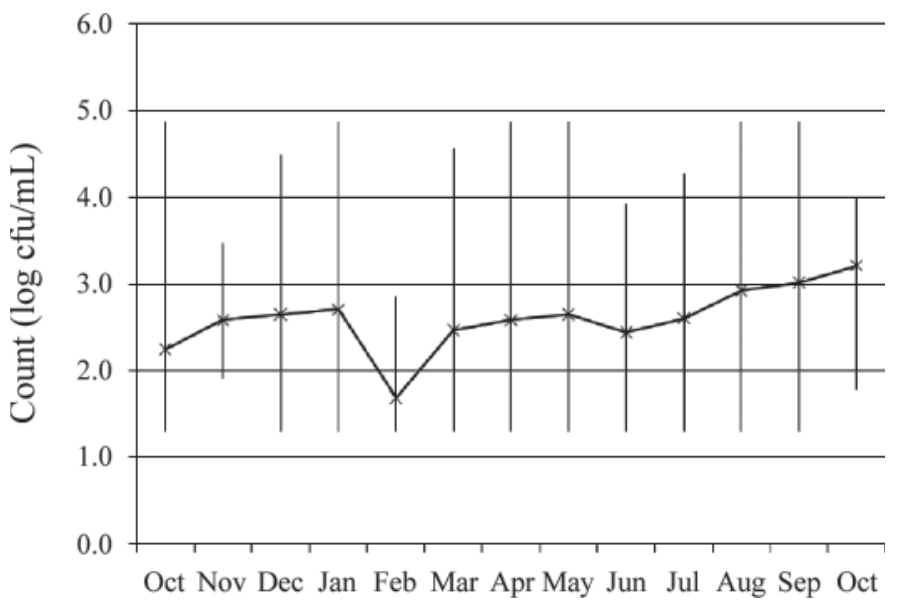

Figure 1. Pseudomonad counts in fresh raw cow milks from 37 herds sampled monthly for $13 \mathrm{mo}$. The vertical lines represent minimum and maximum values for bacterial counts $(\log \mathrm{cfu} / \mathrm{mL})$.

in pseudomonads (Figure 1) and other milk quality parameters (Table 1).

As expected, we observed the generally accepted seasonal variations for total fats and total proteins. Total fat (mean summer value $36.3 \mathrm{~g} / \mathrm{L}$, mean winter value $38.0 \mathrm{~g} / \mathrm{L}$ ) and total protein (mean summer value 32.1 $\mathrm{g} / \mathrm{L}$, mean winter value $32.8 \mathrm{~g} / \mathrm{L}$ ) were lower in summer. Somatic cell counts were higher in summer, as were those for coliforms and coagulase-positive staphylococci. These results were consistent with the generally accepted patterns of milk quality variation (Jayarao et al., 2004; Kuhn et al., 2006; Pavel and Gavan, 2011). They confirmed that our sampling was representative of French cattle herd milks from small farms practicing summer grazing and winter housing. For pseudomonads, although the trend showed a decrease in pseudomonad counts during February and a slight increase at the end of summer, no statistical difference between months could be evidenced during the study period ( $P$ $=0.22$ ). Neither April-May nor August-September appeared to be critical periods, as suggested by ripeners. The $P$-value for a seasonal effect was 0.42 , confirming the absence of statistical differences for pseudomonad counts in nonrefrigerated raw milks. As these results were clearly weakened by the observed high standard deviations, we carried out several statistical tests (oneway ANOVA and multiple range tests with a confidence level of $95 \%$ ) and excluded, for example, the producers who presented the highest variability; none of them showed any evidence of a monthly or seasonal effect on pseudomonad counts ( $P$-value 0.34 or 0.68$)$.

To seek possible correlations between pseudomonad counts and coagulase-positive staphylococci, total coliforms, SCC, and fat and protein contents, we performed 
Table 1. Seasonal variations of some quality parameters of fresh raw cow milks sampled monthly for 13 mo

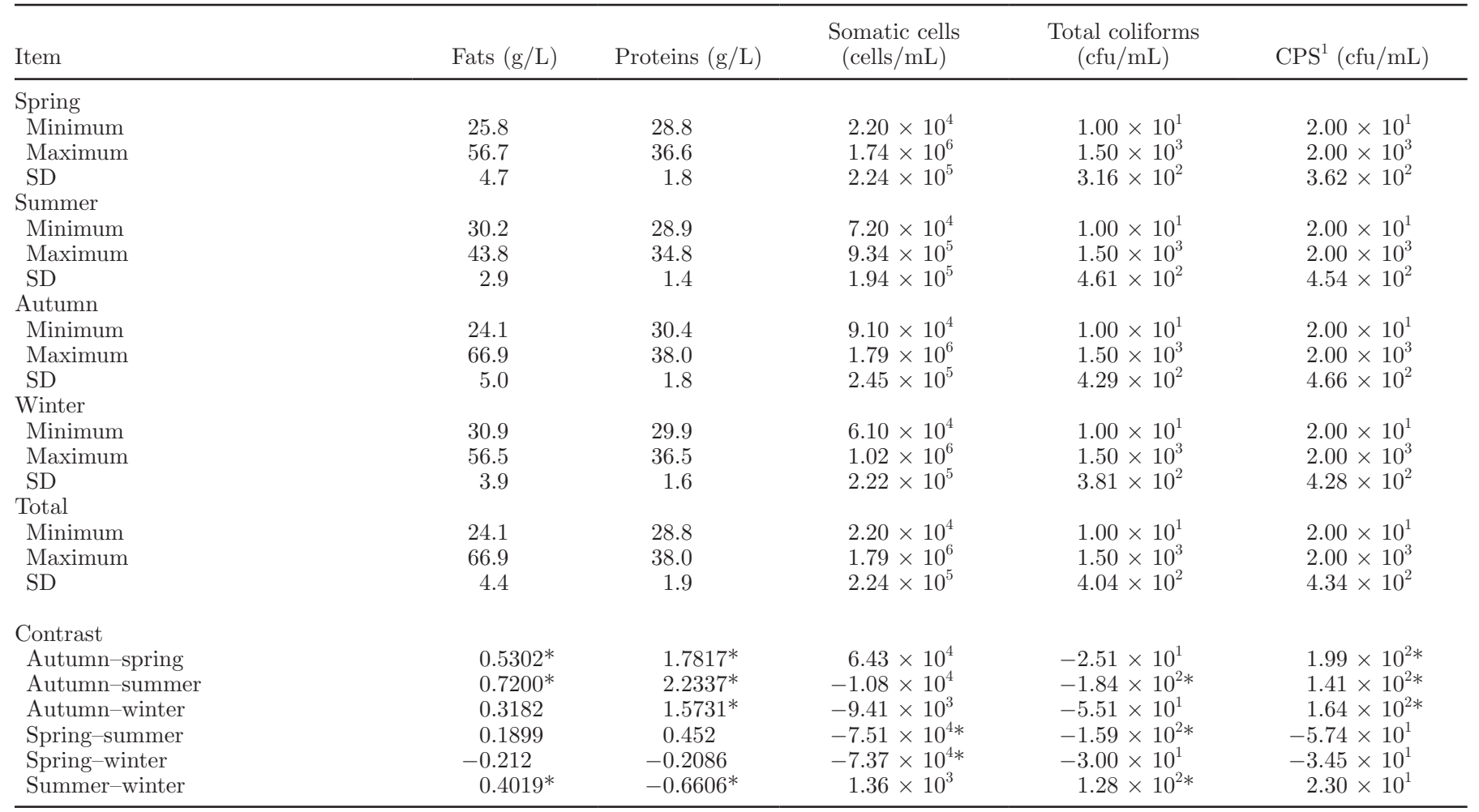

${ }^{1}$ Coagulase-positive staphylococci.

*Statistically different according to an ANOVA multiple range test with 95.0\% CI.

a PCA. The Shapiro-Wilks test $(P<0.0001, \alpha=0.01)$ showed that the data did not follow a normal distribution, so all data were normalized before analysis. The results are presented in Figure 2.

On the factorial map corresponding to this PCA, the first 2 discriminant factors (F1 and F2) explained $48.46 \%$ of the total variance; $27.14 \%$ for axis 1 and $21.32 \%$ for axis 2 . The concentration of pseudomonads in milk was correlated positively with coliform concentration $\left(\mathrm{R}^{2}=0.31\right)$. Each of the pseudomonad and coliform parameters explained more than $30 \%$ of the variability on the F2 axis, whereas the protein and fat contents explained 14 and $18 \%$ of the variability expressed on the axis. These last 2 parameters were correlated negatively with the concentration of pseudomonads in milks. The concentrations of coagulasepositive staphylococci and SCC were correlated positively $\left(\mathrm{R}^{2}=0.26, P<0.0001\right)$, contributing slightly to the explanation of total variability on the F2 axis. No correlation was detected for total SCC or coagulasepositive staphylococci and pseudomonad counts $(P=$ 0.26 and $P=0.34$, respectively); this seemed consistent, because non-aeruginosa Pseudomonas spp. have never, to our knowledge, been associated with mastitis. No correlation was detected for pseudomonad counts and total fats or total proteins $(P=0.78$ and $P=$ 0.95 , respectively). Pearson correlation coefficients are presented in Table 2.

Several authors have sought milk quality markers of on-farm hygiene practices or markers that are of interest for cheesemaking technology (Hutchison et al., 2005), but most failed to identify any reproducible, stable correlations between the different milk microflora categories (Martin et al., 2011b). In an extensive study on 749 milk samples collected at several times during winter, spring, and summer $(24,48$, or $72 \mathrm{~h}$ after milking and storage at low temperature) in 105 herds from 3 regions of France, Heuchel et al. (1995) noted that psychrotrophic counts varied greatly between farms but were always dominant in milks that had a mean value of $1.60 \times 10^{4} \mathrm{cfu} / \mathrm{mL}$ for total bacterial counts $(\mathbf{T B C})$; in these cases, the mean value for psychrotrophics was $2.89 \times 10^{3} \mathrm{cfu} / \mathrm{mL}$ (i.e., $18 \%$ ). By comparison, psychrotrophic bacteria accounted for $25 \%$ of TBC $(1.26 \times$ $10^{5} \mathrm{cfu} / \mathrm{mL}, \mathrm{n}=1,120$; Institut Technique du Gruyère, La Roche sur Foron, France, personal communication, 1987 ) and $29.4 \%$ for milks with TBC of $7.60 \times 10^{4}$ $\mathrm{cfu} / \mathrm{mL}, \mathrm{n}=402$; Villar et al., 1996). In these studies, the correlation coefficient between psychrotrophics and coliforms ranged from 0.43 to 0.7 , which is consistent 
Table 2. Correlations (Pearson correlation coefficient, PCC) between some fresh raw cow milk quality parameters ${ }^{1}$

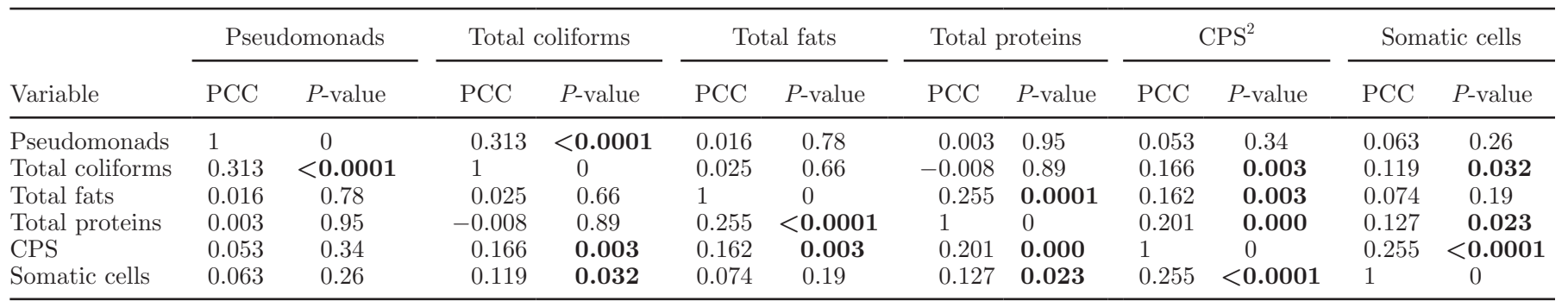

${ }^{1}$ Bold font highlights statistically significant $P$-values $(P<0.05)$.

${ }^{2}$ Coagulase-positive staphylococci.

with our study, but we note that numerous coliforms were probably counted as psychrotrophics in the protocols used in the earlier studies, which was not the case for the protocol used in the current study. Coliforms mainly originate from animal or human feces and are generally considered indicators of poor herd hygiene, unsanitary milking practices, or improperly washed and maintained equipment. Pseudomonas spp. are known to originate mainly from water. The observed correlation between pseudomonads and coliforms suggests that failures in hygiene practices represent a significant source of contamination of milk by pseudomonads and

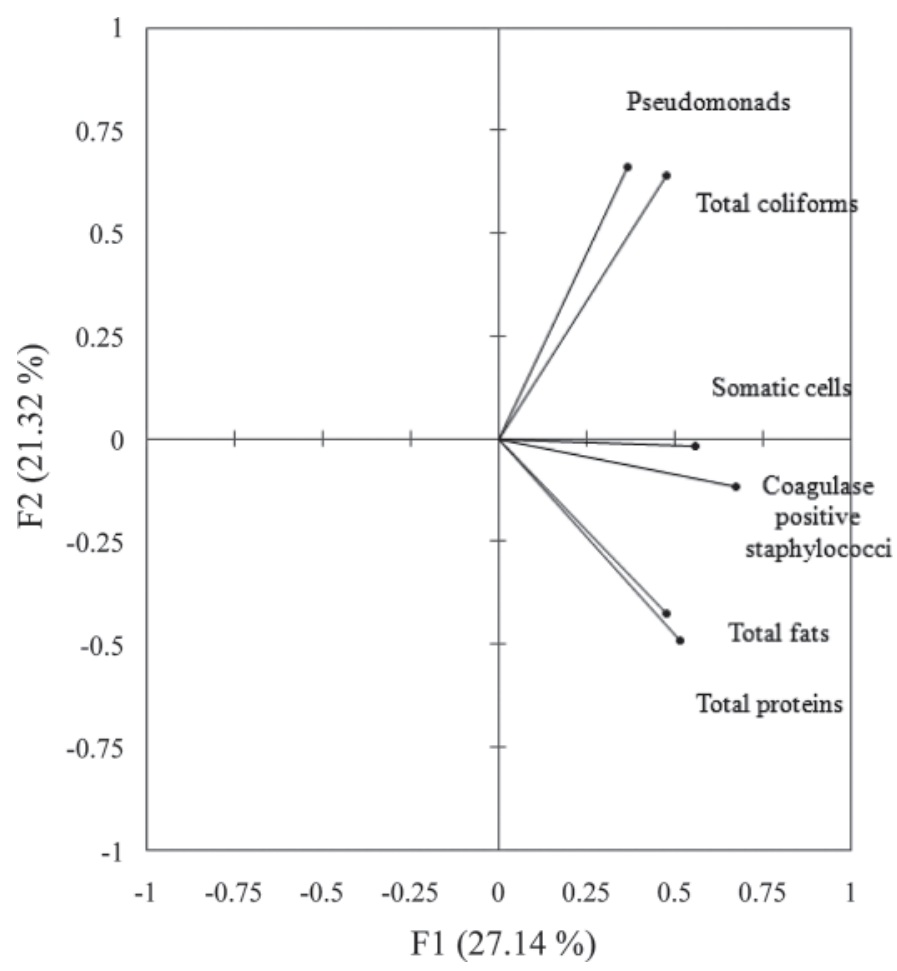

Figure 2. Principal component analysis factorial map for the quality parameters of fresh raw cow's milks (pseudomonads, coagulasepositive staphylococci, total coliforms, and SCC, fat, and protein contents) collected monthly for 13 mo in 37 dairy farms. Together, factors (F) 1 and 2 accounted for $48.86 \%$ of the variation. offers an explanation for the observed high variation values.

\section{Milking Practices and Routes of Contamination by Pseudomonads}

We undertook a survey of milking and sanitizing practices in 7 farm houses (designated $A$ to $G$ ) manufacturing Saint-Nectaire cheese according to the PDO specifications. The farms were selected based on hierarchical clustering performed on the pseudomonad counts from the herd milks described previously. The clustering sorted the farmhouse milks into 4 groups, as follows. Group 1 consisted of 29 farms with low pseudomonad counts in milk, ranging from $5.19 \times 10^{1}$ to 5.45 $\times 10^{3} \mathrm{cfu} / \mathrm{mL}$ and mean standard deviations ranging from $3.26 \times 10^{1}$ to $1.15 \times 10^{4}$. Group 2 consisted of 5 farms with medium pseudomonad counts in milk, ranging from $7.06 \times 10^{3}$ to $1.08 \times 10^{4} \mathrm{cfu} / \mathrm{mL}$ and mean standard deviations ranging from $2.25 \times 10^{4}$ to $2.49 \times 10^{4}$. Group 3 consisted of 2 farms with higher pseudomonad counts in milks of $1.40 \times 10^{4} \mathrm{cfu} / \mathrm{mL}$ and $1.59 \times 10^{4} \mathrm{cfu} / \mathrm{mL}$ and standard deviations of 3.01 $\times 10^{4}$ and $3.30 \times 10^{4}$, respectively. Group 4 consisted of 1 farm; its arithmetic medium value for pseudomonad counts over the year was $2.54 \times 10^{4} \mathrm{cfu} / \mathrm{mL}$, with a mean standard deviation of $3.85 \times 10^{4}$. Thus, 6 of the selected farms (A, B, C, D, E, and F) belonged to group 1 and the seventh $(\mathrm{G})$ belonged to group 4 . The same hierarchical clustering was performed on the total coliform counts and total coagulase-positive staphylococci from the same milks. Briefly, 4 producers (A, B, $\mathrm{C}$, and D) from group 1 were classified in cluster 1 from coliforms $\left(1.00 \times 10^{1}\right.$ to $1.94 \times 10^{2} \mathrm{cfu} / \mathrm{mL}$ and mean standard deviations ranging from $0.00 \times 10^{0}$ to 2.94 $\left.\times 10^{2}\right)$ and group 1 from staphylococci $\left(2.23 \times 10^{1}\right.$ to $2.70 \times 10^{2} \mathrm{cfu} / \mathrm{mL}$ and mean standard deviation 7.62 $\times 10^{1}$ ). One producer (E) from pseudomonad group 1 was classified in coliform group 1 but in staphylococci group $2\left(3.04 \times 10^{2}\right.$ to $6.57 \times 10^{2} \mathrm{cfu} / \mathrm{mL}$ and mean standard deviation $\left.1.40 \times 10^{2}\right)$. One producer $(\mathrm{F})$ from 
pseudomonad group 1 was classified in coliform group 2 but in staphylococci group 1 . The producer classified in pseudomonad group $4(\mathrm{G})$ was classified in coliform group 3 (from $2.57 \times 10^{2}$ to $4.44 \times 10^{2} \mathrm{cfu} / \mathrm{mL}$ and standard deviation from $5.65 \times 10^{2}$ to $7.53 \times 10^{2}$ ) and staphylococci group 1. These results support the hypothesis of a relationship between pseudomonads and coliforms but not with other milk quality parameters.

The 7 selected farmhouses were equipped with automatic milking machines, and sanitizing programs were set for the machines. The sanitizing process consisted of 3 different main phases: prerinse with sink water, cleaning and disinfection in 2 steps with alternating acid and alkaline chlorine-based formulated products, and postrinse. The sanitizers were similar for all 7 workshops; they were recommended and sold by the PDO association allowing for local water hardness (very low in the study region) and the observed constraints in use. The PDO association for Saint-Nectaire cheese also offers advice, help, control and intervention to address any problems, and for hygiene procedures and technical maintenance of equipment. All the data concerning the survey and microbial analysis are given as supplementary material (Table S1, available online at http://www.journalofdairyscience.org/).

In the 7 dairy workshops, samples were collected throughout the milking process. In sink water used for milking machines, pseudomonad counts ranged from $<1.00 \times 10^{1} \mathrm{cfu} / \mathrm{L}(\mathrm{C}, \mathrm{D}, \mathrm{E}, \mathrm{G})$ to $7.0 \times 10^{5} \mathrm{cfu} / \mathrm{L}(\mathrm{B})$. In water from the end of the prerinsing of the milking machine before the cleaning cycle, the pseudomonad counts rose in almost all the workshops, reaching between $1.00 \times 10^{1}$ and $1.10 \times 10^{4} \mathrm{cfu} / \mathrm{L}$. This observation suggests that the first flow of water probably picked up bacteria embedded in biofilms on the inner surfaces of the milking machine (which are made of rubber, stainless steel or plastics, well known to favor bacterial adhesion; Teixeira et al., 2005). During the milking machine washing and sanitizing steps, pseudomonad counts in water samples were low $(<1.00 \times$ $\left.10^{1} \mathrm{cfu} / \mathrm{L}\right)$, suggesting high efficiency of the sanitizing products, at least temporarily. For 6 of the 7 producers studied (A, B, C, D, E, and G), the water of the last rinse was of high microbial quality $\left(<1.00 \times 10^{1} \mathrm{cfu} / \mathrm{L}\right)$, but presented a modified $\mathrm{pH}$ compared with sink water. This undoubtedly reflected the presence of residual biocides in the machine after milking. In all cases, we observed a decrease in water temperature between the beginning and the end of the milking machine sanitizing procedure. At the beginning, temperatures ranged from $60^{\circ} \mathrm{C}$ to $87^{\circ} \mathrm{C}$, compared with 29 to $37^{\circ} \mathrm{C}$ (A, B, C, $\mathrm{D}$, and $\mathrm{F}$ ) to $53^{\circ} \mathrm{C}(\mathrm{G})$ at the end. Insufficient hot water supply constituted a critical failure in the sanitizing procedure mainly for producers $\mathrm{B}$ and $\mathrm{C}$. Two other points were clearly identified as contamination sources: the milking machine filters, with contamination ranging from $5.00 \times 10^{1} \mathrm{cfu} / \mathrm{cm}^{2}$ (D) to $3.10 \times 10^{4} \mathrm{cfu} /$ $\mathrm{cm}^{2}$ (B), and the washing rubber cups, where pseudomonads could be counted at levels reaching $7.80 \times$ $10^{6} \mathrm{cfu} / \mathrm{cm}^{2}$ (B) during the milking process. On teats, pseudomonad counts were always $<1.00 \times 10^{1} \mathrm{cfu} / \mathrm{cm}^{2}$ during milking (except for producer B: $4.00 \times 10^{2} \mathrm{cfu} /$ $\mathrm{cm}^{2}$ ), consistent with the observed practice of udder washing before milking with cloths kept in warm water with added disinfectant.

Our sample size did not allow any statistical inference. The search for statistical relationships between on-farm practices proved fruitless even for producer $G$, who presented high variability and strong contamination of the milk by pseudomonads. This suggests that the results of sample analysis carried out in a particular instance cannot be extrapolated. Thus, in the case of workshops where good hygienic practices are broadly applied, contamination by pseudomonads may be sporadic and due to a single point of failure of the hygiene practices, including one-time water contamination. These conclusions agree with an in-depth analysis of the effects of the sanitizing procedure for milking equipment on bacterial counts of bulk tank milk recently undertaken by Bava et al. (2011). The authors notably highlighted the importance of water temperature during the cleaning and sanitation of the milking machine and the relationship with coliform counts. In our case, we also noted high variation in water quality with regard to pseudomonads. Water is known to be a major source of pseudomonad contamination of milk (Jayarao, 1999; Perkins et al., 2009), and although the microbial quality of drinking water is strictly regulated and controlled by the legislation in force, non-aeruginosa Pseudomonas spp. are not subject to surveillance. Their presence at high concentrations in chlorinated or nonchlorinated water used at all stages of sanitation and surface rinsing has often been observed by technicians (data not shown) and can be unequivocally incriminated in hygiene failure, despite the observed obvious goodwill of operators (Thomas and Thomas, 1973; Leriche et al., 2004). Further studies of the prevalence and variability of non-aeruginosa Pseudomonas counts in water in relation to milk microbial quality should be conducted, as has been performed for Escherichia coli and coliforms (Perkins et al., 2009).

Pseudomonas and related species are found in winter and summer in large numbers in all the major natural environments: soil, plant rhizosphere, insects, humans, and fresh or marine waters (Spiers et al., 2000), and even in clouds, where their involvement in the natural water cycle has been recently shown (Delort et al., 2010). From these environments, they can contaminate 
raw materials and products throughout the food production and processing chain. In raw milk cheeses, their presence at high levels can be attributed to 3 main factors: (1) abundance in raw milk, (2) growth during processing, and (3) introduction into products during cheesemaking. The present work set out to study the first of these factors to determine whether the observed seasonal occurrence of cheese defects due to pseudomonad contamination was correlated with seasonal variations of pseudomonad counts in milks. We also sought to determine the origin of the pseudomonads present at high concentration in milks. In this 1-yr study, no statistical differences in pseudomonad counts for season or month could be demonstrated, due to the very high variability observed within farm and between farms. The seasonal variations in pseudomonad or psychrotrophic counts in milk have been the subject of several studies, but the data are very difficult to compare because the nature of the samples (2 or $3 \mathrm{~d}$ refrigeration or nonrefrigerated milk, herd milk vs. bulk milk), the flora counted, and the methods used vary widely. In addition, the results and conclusions drawn are often sharply conflicting. The broad genotypic and phenotypic diversity of pseudomonads in raw milks has been described by several authors (Wiedmann et al., 2000; Dogan and Boor, 2003; Martins et al., 2006; MunschAlatossava and Alatossava, 2006). The diversity and enzymatic activities of these bacteria vary according to season. For example, Hantsis-Zacharov and Halpern (2007) have observed that in psychrotrophic bacteria of refrigerated milks (4 farms in Israel sampled monthly for $10 \mathrm{mo}$ ) gammaproteobacteria, with Pseudomonas as the main genus, dominated chiefly in spring and winter. Likewise, Marchand et al. (2009) demonstrated the seasonal influence on the proteolytic capacity of Pseudomonas spp. isolated from raw milks. More specifically, winter isolates of Pseudomonas spp. exhibited higher heat-resistant proteolytic activity than summer isolates $(n=103)$. These observations were confirmed recently by De Jonghe et al. (2011), who observed differences in the evolution patterns of Pseudomonas species in raw milks stored at the same temperature. Such phenotypic differences in relation to seasonal period of milking have also been observed for other dairy microflora; for example, Lactococcus (Corroler et al., 1998). Finally, close inspection of the data showed that few if any quantitative differences could be observed for fresh-drawn milk, whereas refrigerated milk (up to $72 \mathrm{~h}$ ) exhibited marked differences between seasons.

\section{CONCLUSIONS}

The empirical description of seasonal emergence of pseudomonad-induced cheese spoilage may be at- tributed to many different factors, with the seasonal variability of pseudomonad diversity and phenotypic characteristics as the prime factor. However, many other season-linked milk quality parameters can be considered, such as the concentration of casein, urea, or the nature and concentration of fats and minerals. All of these, together with the indigenous microbial ecosystem, may seasonally modulate the growth and the enzymatic activities of pseudomonads involved in cheese spoilage. The precise relationship between chemical composition of milk microbial ecosystems and growth of Pseudomonas in cheeses is still unknown, but should be of concern for all raw milk cheesemakers. The determination of quantitative criteria for pseudomonad counts in milks used for raw milk cheese manufacturing is still premature, as they may be strain-dependent and related to the chemical composition of milks. Hence, in small-scale workshops producing raw milk cheeses, the only strategy currently available to protect produce from this spoilage microflora is an adequate hygiene program with particular attention paid to water quality.

\section{ACKNOWLEDGMENTS}

We are indebted to DATAR - Massif Central for financial support. We also sincerely thank the Pôle Fromager AOC Massif Central (Aurillac, France), the Saint-Nectaire cheese trade (Besse en Chandesse, France), and the farmers for their collaboration.

\section{REFERENCES}

Bava, L., M. Zucali, A. Sandrucci, M. Brasca, L. Vanoni, L. Zanini, and A. Tamburini. 2011. Effect of cleaning procedure and hygienic condition of milking equipment on bacterial count of bulk tank milk. J. Dairy Res. 78:211-219. http://dx.doi.org/10.1017/ S002202991100001X.

Champagne, C. P., R. R. Laing, D. Roy, A. A. Mafu, and M. W. Griffiths. 1994. Psychrotrophs in dairy products: Their effects and their control. Crit. Rev. Food Sci. Nutr. 34:1-30.

Corroler, D., I. Mangin, N. Desmasures, and M. Gueguen. 1998. An ecological study of lactococci isolated from raw milk in the Camembert cheese registered designation of origin area. Appl. Environ. Microbiol. 64:4729-4735.

Cousin, M. A., and E. H. Marth. 1977. Psychrotrophic bacteria cause changes in stability of milk to coagulation by rennet or heat. J. Dairy Sci. 60:1042-1047.

De Jonghe, V., A. Coorevits, K. Van Hoorde, W. Messens, A. Van Landschoot, P. De Vos, and M. Heyndrickx. 2011. Influence of storage conditions on the growth of Pseudomonas species in refrigerated raw milk. Appl. Environ. Microbiol. 77:460-470.

Delort, A.-M., M. Vaïtilingom, P. Amato, M. Sancelme, M. Parazols, G. Mailhot, P. Laj, and L. Deguillaume. 2010. A short overview of the microbial population in clouds: Potential roles in atmospheric chemistry and nucleation processes. Atmos. Res. 98:249-260.

Desmasures, N., and M. Gueguen. 1997. Monitoring the microbiology of high quality milk by monthly sampling over 2 years. J. Dairy Res. 64:271-280. http://dx.doi.org/10.1017/S0022029996002130.

Dogan, B., and K. J. Boor. 2003. Genetic diversity and spoilage potentials among Pseudomonas spp. isolated from fluid milk products 
and dairy processing plants. Appl. Environ. Microbiol. 69:130138 .

Fairbairn, D. J., and B. A. Law. 1986. Proteinases of psychrotrophic bacteria: Their production, properties, effects and control. J. Dairy Res. 53:139-177.

Ferré, D. 2003. Méthodologie du diagnostic à l'échelle du troupeau, application en élevage bovin laitier. DVM Thesis. Université Paul Sabatier, Toulouse, France.

Gennari, M., and F. Dragotto. 1992. A study of the incidence of different fluorescent Pseudomonas species and biovars in the microflora of fresh and spoiled meat and fish, raw milk, cheese, soil and water. J. Appl. Bacteriol. 72:281-288. http://dx.doi. org/10.1111/j.1365-2672.1992.tb01836.x.

Gunasekera, T. S., M. R. Dorsch, M. B. Slade, and D. A. Veal. 2003. Specific detection of Pseudomonas spp. in milk by fluorescence in situ hybridization using ribosomal RNA directed probes. J. Appl. Microbiol. 94:936-945. http://dx.doi.org/10.1046/j.13652672.2003.01930.x

Hantsis-Zacharov, E., and M. Halpern. 2007. Culturable psychrotrophic bacterial communities in raw milk and their proteolytic and lipolytic traits. Appl. Environ. Microbiol. 73:7162-7168.

Heuchel, V., J. Pellouin, L. Sommellier, L. F. D. Lequenne, and J. F. Chamba. 1995. Caractérisation microbiologique et aptitudes technologiques des laits ultra-propres. Institut de l'élevage, Paris, France.

Hutchison, M. L., D. J. I. Thomas, A. Moore, D. R. Jackson, and I. Ohnstad. 2005. An evaluation of raw milk microorganisms as markers of on-farm hygiene practices related to milking. J. Food Prot. 68:764-772.

ISO (International Organization for Standardization). 1999. Microbiology of food and animal feeding stuffs - Horizontal method for the enumeration of coagulase-positive staphylococci (Staphylococcus aureus and other species. Part 2: technique using rabbit plasma fibrinogen agar medium. ISO 6888-2. ISO, Geneva, Switzerland.

ISO (International Organization for Standardization). 2000. Whole milk-Determination of milkfat, protein and lactose contentGuidance on the operation of mid-infrared instruments. NF ISO 9622. ISO, Geneva, Switzerland.

ISO (International Organization for Standardization). 2008. MilkEnumeration of somatic cells-Part 1: Microscopic method (Reference method). NF EN ISO 13366-1. ISO, Geneva, Switzerland.

ISO (International Organization for Standardization). 2009. Microbiology of food and animal feeding stuffs - Enumeration of presumptive coliforms by colony count technique at $30^{\circ} \mathrm{C}$. NF V08-050. ISO, Geneva, Switzerland.

Jaspe, A., P. Oviedo, L. Fernandez, P. Palacios, and C. Sanjose. 1995. Cooling raw milk: Change in the spoilage potential of contaminating pseudomonas. J. Food Prot. 58:915-921.

Jayarao, B. M., S. R. Pillai, A. A. Sawant, D. R. Wolfgang, and N. V. Hegde. 2004. Guidelines for monitoring bulk tank milk somatic cell and bacterial counts. J. Dairy Sci. 87:3561-3573.

Jayarao, B. M., and L. Wang. 1999. A study on the prevalence of gramnegative bacteria in bulk tank milk. J. Dairy Sci. 82:2620-2624.

Kuhn, M. T. J. L. Hutchison, and H. D. Norman. 2006. Effects of length of dry period on yields of milk fat and protein, fertility and milk somatic cell score in the subsequent lactation of dairy cows. J. Dairy Res. 73:154-162. http://dx.doi.org/10.1017/ S0022029905001597.

Kumaresan, G., R. Annalvilli, and K. Sivakumar. 2007. Psychrotrophic spoilage of raw milk at different temperatures of storage. J. Appl. Sci. Res. 3:1383-1387.

Ledenbach, L. H., and R. T. Marshall. 2009. Microbiological spoilage of dairy products. Pages 41-67 in Compendium of the Microbiological Spoilage of Foods and Beverages. W. H. Sperber and M. P. Doyle, ed. Springer Science+Business Media, New York, NY.

Leitner, G., N. Silanikove, S. Jacobi, L. Weisblit, S. Bernstein, and U. Merin. 2008. The influence of storage on the farm and in dairy silos on milk quality for cheese production. Int. Dairy J. 18:109-113.

Leriche, F., A. Bordessoules, K. Fayolle, R. Karoui, K. Laval, L. Leblanc, and E. Dufour. 2004. Alteration of raw-milk cheese by Pseudomonas spp.: Monitoring the sources of contamination using fluorescence spectroscopy and metabolic profiling. J. Microbiol Methods 59:33-41.

Marchand, S., K. Heylen, W. Messens, K. Coudijzer, P. De Vos, K. Dewettinck, L. Herman, J. De Block, and M. Heyndrickx. 2009. Seasonal influence on heat-resistant proteolytic capacity of Pseudomonas lundensis and Pseudomonas fragi, predominant milk spoilers isolated from Belgian raw milk samples. Environ. Microbiol. 11:467-482. http://dx.doi.org/10.1111/j.1462-2920.2008.01785.x.

Martin, N. H., S. C. Murphy, R. D. Ralyea, M. Wiedmann, and K. J. Boor. 2011a. When cheese gets the blues: Pseudomonas fluorescens as the causative agent of cheese spoilage. J. Dairy Sci. 94:3176-3183.

Martin, N. H., M. L. Ranieri, S. C. Murphy, R. D. Ralyea, M. Wiedmann, and K. J. Boor. 2011b. Results from raw milk microbiological tests do not predict the shelf-life performance of commercially pasteurized fluid milk. J. Dairy Sci. 94:1211-1222.

Martins, M. L., C. L. O. Pinto, R. B. Rocha, E. F. de Araújo, and M. C. D. Vanetti. 2006. Genetic diversity of gram-negative, proteolytic, psychrotrophic bacteria isolated from refrigerated raw milk. Int. J. Food Microbiol. 111:144-148.

Meer, R. R., J. Baker, F. W. Bodyfelt, and M. W. Griffiths. 1991. Psychrotrophic Bacillus spp. in fluid milk products: A review. J. Food Prot. 54:969-979.

Morita, R. Y. 1975. Psychrophilic bacteria. Bacteriol. Rev. 39:144167.

Munsch-Alatossava, P., and T. Alatossava. 2006. Phenotypic characterization of raw milk-associated psychrotrophic bacteria. Microbiol. Res. 161:334-346.

Pavel, E. R., and C. Gavan. 2011. Seasonal and milking-to-milking variations in cow milk fat, protein and somatic cell counts. Notulae Scientia Biologicae 3:20-23.

Perkins, N. R., D. F. Kelton, K. J. Hand, G. MacNaughton, O. Berke, and K. E. Leslie. 2009. An analysis of the relationship between bulk tank milk quality and wash water quality on dairy farms in Ontario, Canada. J. Dairy Sci. 92:3714-3722.

Piton, C., and J. Richard. 1982. Causes de contamination microbienne d'importance moyenne du lait dans un groupe de fermes de la région de Rennes. Lait 62:67-74. http://dx.doi.org/10.1051/ lait:1982611-6125.

Richard, J., and C. Houssu. 1983. Nature de la flore microbienne dominante et sous-dominante des laits crus très pollués. Lait 63:148170. http://dx.doi.org/10.1051/lait:1983625-62612.

Sauvée, O. 2007. Hygiène de la machine à traire: Méthode de contrôle. Etude du Département Techniques d'Elevage et Qualité. Institut de l'élevage, Paris, France.

Sørhaug, T., and L. Stepaniak. 1997. Psychrotrophs and their enzymes in milk and dairy products: Quality aspects. Trends Food Sci Technol. 8:35-41.

Spiers, A. J., A. Buckling, and P. B. Rainey. 2000. The cause of Pseudomonas diversity. Microbiology 146:2345-2350.

Teixeira, P., Z. Lopes, J. Azeredo, R. Oliveira, and M. J. Vieira. 2005. Physico-chemical surface characterization of a bacterial population isolated from a milking machine. Food Microbiol. 22:247-251.

Ternström, A., A. M. Lindberg, and G. Molin. 1993. Classification of the spoilage flora of raw and pasteurized bovine milk, with special reference to Pseudomonas and Bacillus. J. Appl. Bacteriol. $75: 25-34$.

Thomas, S. B., and B. F. Thomas. 1973. Psychrotrophic bacteria in refrigerated bulk-collected raw milk. Dairy Industries 38:11-15.

Verdier-Metz, I., V. Michel, C. Delbès, and M.-C. Montel. 2009. Do milking practices influence the bacterial diversity of raw milk? Food Microbiol. 26:305-310.

Villar, A., J. A. García, L. Iglesias, M. L. García, and A. Otero. 1996 Application of principal component analysis to the study of microbial populations in refrigerated raw milk from farms. Int. Dairy J. 6:937-945.

Wiedmann, M., D. Weilmeier, S. S. Dineen, R. Ralyea, and K. J. Boor 2000. Molecular and phenotypic characterization of Pseudomonas spp. isolated from milk. Appl. Environ. Microbiol. 66:2085-2095. 